Apresentação 


\section{FÓRUM DE DESENVOLVIMENTO TERRITORIAL E MEIO AMBIENTE Agroecologia: práticas alternativas e produção de alimentos em uma sociedade insustentável}

Esta edição do Fórum teve como tema central a Agroecologia. Trata-se de um tema de natureza multidisciplinar, definido por meio de três diferentes perspectivas: 1) enquanto prática agrícola diferenciada das formas convencionais; 2) enquanto movimento social; 3) enquanto disciplina científica multidisciplinar.

Em primeiro lugar, podemos afirmar que a Agroecologia possui um caráter transformador das formas de produção no campo, ao propor a reorganização de agroecossistemas e visando reduzir sua vulnerabilidade às pragas e doenças, por opções tecnológicas com baixos aportes em capital, com alta eficiência no uso da terra e para produção de alimentos de maior qualidade biológica. Pressupõe processos de autonomia a agricultores familiares em relação aos complexos agroindustriais, bem como a criação de mercados camponeses, justos e institucionais - tais como as prefeituras, a merenda escolar, feiras e grupos de consumidores.

Por outro lado, a Agroecologia compõe um movimento social mais abrangente com pautas sociais e ambientais, que enfrenta questões como a concentração fundiária e produtiva, com reflexos diretos na distribuição das riquezas geradas pelo setor agrícola da economia. Tais movimentos sociais, críticos à estrutura fundiária concentrada que temos no Brasil e no mundo, reforçam os impactos negativos que a grande agricultura causa aos diferentes biomas. Os desmatamentos, os monocultivos e o emprego de pacotes tecnológicos que causam degradação ambiental e problemas à saúde humana, como no caso dos agrotóxicos, entram nesta pauta de denúncias.

Por fim, uma disciplina científica que enfoca o estudo da agricultura sob uma perspectiva ecológica e com um marco teórico-metodológico cuja finalidade é analisar os processos agrícolas de forma abrangente e ultrapassando a mera produtividade, mas incorporando dimensões sócio-econômicas, biológicas e agronômicas. Uma área científica que enfrenta forte resistência, em função de que se insere nas disputas materiais e simbólicas sobre os rumos do desenvolvimento agrícola e rural, em âmbitos local, regional e nacional.

As discussões no Fórum abrangeram a luta por reconhecimento e as políticas públicas voltadas à Agroecologia, os marcos regulatórios, as experiências práticas em diferentes realidades que atestam sua viabilidade como paradigma de produção, a adequação da agricultura familiar aos princípios agroecológicos, os problemas da agricultura convencional, as contaminações humanas e ambientais em função do uso de agrotóxicos.

Este evento foi realizado no dia 04 de dezembro de 2016, promovido pelo Programa de Pós-graduação em desenvolvimento territorial e meio ambiente. Cabe destacar que esta foi a oitava edição deste evento, que vem mantendo sua periodicidade anual. Os resumos apresentados estão publicados a seguir.

Prof. Dr. Henrique Carmona Durval (Comissão organizadora) 